\title{
Pengembangan Cabang Ranting (PCR) Era Pandemi di Ranting Kenjeran, Surabaya
}

\author{
M. Hanifuddin Hakim ${ }^{1 *}$, Imtihanatul Ma'isyatuts Tsalitsah ${ }^{2}$ \\ ${ }^{1}$ Fakultas Teknik, ${ }^{2}$ Fakultas Psikologi Universitas Muhammadiyah Surabaya \\ hanifuddinhakim@ft.um-surabaya.ac.id ${ }^{1}$,imtihanatul@fpsi.um-surabaya.ac.id ${ }^{2}$ \\ *Corresponding author: hanifuddinhakim@ft.um-surabaya.ac.id
}

\begin{abstract}
ABSTRAK
Pimpinan Cabang Ranting Bulak merupakan salah satu Cabang Muhammadiyah di wilayah Surabaya Utara. Ranting Bulak berdiri pada tahun 2012, karena terjadinya pemekaran wilayah dari cabang kenjeran menjadi cabang bulak. Di masa pandemi ini, Pemerintah menganjurkan agar segala aktivitas dilakukan di rumah, hal tersebut telah di tetapkan pada edaran surat kemendikbud. Sehingga pelaksanaan segala kegiatan Cabang dan Ranting Muhammadiyah banyak mengalami kendala sehingga banyak pula kegiatan-kegiatan yang tidak terlaksana sesuai dengan yang diprogramkan. Hal inilah yang melatarbelakangi penulis untuk memberikan edukasi kepada masyarakat khususnya pimpinan dan warga Muhammadiyah setempat agar tetap produktif di era pandemi dengan mengajak mereka melalui kegiatan pengembangan Pimpinan Cabang dan Ranting Kuliah Kerja Nyata Universitas Muhammadiyah Surabaya. Penelitian ini bertujuan untuk mengetahui bagaimana efektifitas Pimpinan dan Warga Muhammadiyah Bulak dalam melaksanakan kegiatan yang telah diprogramkan.

Kegiatan ini dilakukan dengan menggunakan pendekatan model community development yaitu upaya mempersiapkan masyarakat seiring dengan langkah memperkuat kelembagaan masyarakat agar mereka mampu mewujudkan kemajuan, kemandirian, dan kesejahteraan dalam suasana keadilan sosial yang berkelanjutan. Berdasarkan permasalahan yang dihadapi Cabang dan Ranting Muhammadiyah di Kecamatan Kenjeran yang telah diidentifikasi, maka solusi yang ditawarkan dalam program KKN-PCR ini adalah Pendampingan dan Sosialisasi Cabang dan Ranting Muhammadiyah melalui Pendataan warga dan pendampingan mengurus KTA Muhammadiyah, perbaikan visualisasi informasi dan fasilitas masjid agar masyarakat menjadikan masjid sebagai pusat peradaban Islam. Berdasarkan hasil penelitian pengembangan kegiatan cabang dan ranting yang berhasil dilakukan oleh kelompok KKN-PCR Bulak untuk menunjang pengembangan cabang dan ranting Kenjeran adalah Pendataan dan pembuatan KTA, pemakmuran masjid, sosialisasi vaksin, dan santunan kepada anak yatim.
\end{abstract}

Kata Kunci: community development, KKN-PCR, muhammadiyah 


\begin{abstract}
The branches manager or Pimpinan Cabang Ranting Bulak was one of the Muhammadiyah PCRs in the North Surabaya area. Ranting Bulak was established in 2012, due to the regional expansion from the Kenjeran branch to the Bulak branch. During this pandemic, it was recommended to all activities be carried out at home, this has been stipulated in a circular letter from the Ministry of Education and Culture. Hence, the implementation of all activities of Muhammadiyah branches experienced many obstacles. Therefore, many activities were not conducted as the program they have planned. This is the motivation of the author to provide education to the community, especially local Muhammadiyah leaders and residents to remain productive in the pandemic era. They have been invited through the development of branches leaders by real work lectures or Kuliah Kerja Nyata (KKN) from University of Muhammadiyah Surabaya. This study aims to find out how the effectiveness of Bulak Muhammadiyah leaders and citizens in carrying out the activities that have been programmed.

This activity is carried out using a community development model approach, which was an effort to prepare the community along with steps to strengthen community institutions so that they could realize progress, independence, and prosperity in an atmosphere of sustainable social justice. Based on the problems faced by the branches of Muhammadiyah in Kenjeran District that have been identified, the solutions offered in this KKN-PCR program are assistance and socialization of Muhammadiyah Branches through citizen data collection and assistance in making KTA (membership card) of Muhammadiyah, improving information visualization and mosque facilities, so that the community makes the mosque is the center of Islamic civilization. According to the results of research on the development of Muhammadiyah branches activities that were successfully carried out by the Bulak KKN-PCR group to support the development of Kenjeran branches were collecting data and making of KTA, prosperity of mosques, socialization of vaccines, and compensation to the orphans.
\end{abstract}

Keywords: Community development, KKN-PCR, and Muhammadiyah.

\section{PENDAHULUAN}

Sampai Artikel ini ditulis, September 2021, Pemerintah Indonesia masih berjuang untuk mengatasi Covid-19. Gelombang kedua yang terjadi disebabkan oleh mutasi virus covid-19 (Varian Delta). Covid-19 varian delta memiliki dampak yang jauh lebih berbahaya dibanding varian awal. Varian delta mampu menular jauh lebih cepat dengan efek yang ditimbulkan ke manusia juga jauh lebih parah (Hartono \& Yusuf, 2021). Lebih dari dua bulan, dimulai tanggal 3 Juli 2021, Pemerintah menarik rem darurat dengan menerapkan

Pemberlakuan

Pembatasan

Kegiatan Masyarakat (PPKM)

Darurat. Hasilnya kini Indonesia semakin menurun kasus konfirmasi positif covid-19.

Data terbaru kasus covid-19 di Indonesia tanggal 11 September 2021, adalah sebagai berikut: 4.163.732 total kasus, 115.676 kasus aktif, sembuh 3.909.355, meninggal 138.701. Kasus konfirmasi positif mengalami trend menurun, tetapi hal ini tidak boleh membuat kita lengah. 
Salah satu organisasi Islam terbesar di Indonesia, yakni Muhammadiyah, sejak awal masuknya covid-19 di Indonesia langsung bergerak cepat dengan membentuk Muhammadiyah Covid-19 Command Center (MCCC). MCCC berkoordinasi untuk mengimplekan berbagai program dan tindakan dalam penanganan

Covid-19.

Muhammadiyah mendorong pemerintah untuk melibatkan semua pihak untuk bekerja bersama-sama dan saling bersinergi serta terbuka terhadap masukan dari berbagai pihak. Muhammadiyah mendukung kebijakan-kebijakan pemerintah dalam menjalankan protokol kesehatan dengan menerbitkan surat edaran kepada semua anggota dan simpatisan (Falahuddin, 2020). Muhammadiyah telah memberikan kontribusi yang signifikan dan terus mengambil peran penting dalam mengatasinya. Antara lain, Muhammadiyah telah membentuk Muhammadiyah Covid-19 Command Center (MCCC), yang merupakan tim khusus yang dibentuk untuk menangani Covid-19. Tim ini telah bekerja sejak didirikan dan terus mengerjakan kasus ini. Hasil kerjanya, termasuk bantuan di bidang kesehatan, pendidikan, dan sosial. Selain itu, melalui Tarjih dan Majelis Tajdid, Muhammadiyah telah memberikan bimbingan agama bagi para anggotanya selama pandemi ini sehingga mereka tidak bingung dalam melakukan ibadah. Dampak dari program dan tindakan ini bahwasanya anggota Muhammadiyah, dan secara umum masyarakat luas, menerima bantuan yang signifikan dalam bidang kesehatan, pendidikan, sosial dan keagamaan (Ichsan, 2020)

Dalam suatu rantai komando hierarki, Cabang dan Ranting merupakan tingkat organisasi yang paling bawah, sehingga secara teratur dilihat dari dasar pemikiran garis kekuasaan dimana pengurus Cabang dan Ranting adalah pihak yang selalu siap sedia untuk memenuhi instruksi dari pimpinan yang di atasnya. Pimpinan Ranting Muhammadiyah

(PRM) merupakan garda terdepan (inisiator) Persyarikatan yang merupakan indikator berhasil atau tidaknya Muhammadiyah sebagai suatu perkembangan gerakan sosial, perkumpulan, atau misi dakwah Islam amar ma'ruf nahi munkar. (Harahap \& Lubis, 2020). 
Kondisi Pandemi secara langsung juga mempengaruhi aktivitas internal Muhammadiyah. Banyak kegiatan-kegiatan dakwah, pendidikan, rapat, koordinasi, pemberdayaan, bahkan Muktamar yang harus ditunda pelaksanaanya atau dirubah metode pelaksanaannya (melalui virtual). Akan tetapi di akar rumput muhammadiyah, yakni Ranting dan Cabang, warga dan simpatisan Muhammadiyah kesulitan untuk menyesuaikan dengan metode virtual. Akibatnya banyak kegiatan-kegiatan dakwah, pendidikan, pemberdayaan yang harus ditiadakan karena masyarakat enggan jika harus mengikuti melalui virtual.

Banyak permasalahan yang dihadapi cabang dan ranting, salah satunya adalah masih banyak Cabang dan Ranting yang belum memiliki kepengurusan lengkap dan belum mampu menjalankan tertib organisasi, administrasi, keuangan, maupun kegiatan (Halim et al., 2018). Begitu pula dengan salah satu Cabang Ranting yang penulis lakukan pendampingan yakni Cabang Bulak, Ranting Kenjeran. Mereka mengalami kendala menjalankan kegiatan organisasi dikarenakan pandemi, sehingga kegiatan-kegiatan rutin seperi kajian tidak bisa berjalan. Kegiatan pengabdian ini merupakan program KKN-PCR (Pengembangan Cabang Ranting).

\section{Sejarah}

Cabang Bulak sendiri merupakan salah satu Cabang Muhammadiyah di wilayah Surabaya Utara. Cabang Bulak berdiri pada tahun 2012, karena terjadinya pemekaran wilayah dari cabang kenjeran menjadi cabang bulak. Pada tahun 2010 Cabang Bulak ini seharusnya berdiri namun terdapat keterlambatan, sehingga realisasinya pada tahun 2012 tepat pada 12 April 2012 Cabang Bulak mengadakan Muscab dengan cabang kenjeran dan cabang baru yang mana terpilihnya ketua bapak Lukmanto selama 2 periode, yakni tahun 2010-2015 dan tahun 2015-2020.

Di masa pandemi ini, dianjurkan segala aktivitas dilakukan di rumah, hal tersebut telah di tetapkan pada edaran surat pemerintah. Sehingga pelaksanaan Muscab yang semestinya belum dilakukan, hal itulah yang menjadikan bapak Lukmanto menjadi ketua dalam 2 periode serta surat keputusan dari Pimpinan Daerah Muhammadiyah (PDM) diperpanjang untuk tahunnya sampai waktu Muktamar.

PCR Bulak berlokasi di Jalan Sukolilo Sukorejo No. 28, Surabaya yang diketuai oleh Bapak Drs. H. Luqmanto. Cabang Bulak terdiri dari 3 ranting yaitu Ranting Sukolilo, 
Ranting Kenjeran dan Ranting Bulak. Ranting Sukolilo telah memiliki banyak AUM yakni Masjid Solihin, Musholah Aisyiyah, Sekolahan salah satunya SD Muhammadiyah 9 Bahari, setiap hari Rabu ganjil dilakukan kajian HPT (Himpunan Putusan Tarjih) dan hari Rabu genap tafsir Al-Qur'an. Di Ranting Sukolilo 95\% merupakan warga Muhammadiyah. Ranting Kenjeran yang berlokasi di dekat Pantai Ria Kenjeran memiliki 4 AUM yaitu Masjid Al-Mustoffa, MTs 19 Surabaya masih terbilang baru sehingga untuk gaji guru masih diperoleh dari hasil iuran, MI AlMustoffa, dan Musholah Hasanah. Sedangkan Ranting Bulak masih belum resmi, disebabkan belum memiliki AUM.

\section{Permasalahan}

Sejak awal pendiriannya, Muhammadiyah memandang dan memutuskan (melalui musyawarah di tingkat ranting, cabang, daerah, wilayah, dan pusat), setidaknya terdapat tiga masalah utama dan sangat mendasar yang dihadapi oleh umat Islam, yaitu: masalah keagamaan, masalah sosial, dan masalah moral (Ma`arif, 2000).

Fenomena pandemi ini menjadikan Cabang Bulak Ranting Kenjeran memiliki kendala, salah satunya data anggota Muhammadiyah terbilang belum lengkap dan diharapkan dengan adanya pendataan ulang anggota Muhammadiyah, akan memudahkan analisa terkait program kerja yang bisa dilakukan pada pimpinan ranting muhammadiyah kenjeran.

Selain itu, pengelolaan masjid yang perlu perbaikan agar memudahkan aktivitas jamaah dalam melaksanakan kegiatan keagamaan, sosial seperti pengajian ibu-ibu Aisyiyah, kegiatan belajar mengajar santri TPQ, kegiatan kepemudaan, bakti sosial dan lain-lain sebagai langkah awal untuk mengembalikan fungsi masjid agar tidak hanya digunakan sebagai tempat ibadah saja, melainkan juga sebagai pusat peradaban ummat. Agar Masjid selalu hidup hampir 24 jam setiap harinya.

Kesadaran masyarakat terkait pentingnya melakukan vaksin di lingkungan sekitar masih cukup buruk. Sehingga perlu adanya sosialiasi pentingnya vaksinasi dengan cara memberikan edukasi secara kultural agar pemahaman terkait fungsi dan manfaat vaksin dapat diterima dengan baik. Dengan pemberian edukasi tersebut juga, dapat menangkal berita-berita hoax tentang vaksin yang banyak sekali berhembus di media sosial sehingga membuat warga menjadi resah dan ketakutan karena vaksin. Kami berharap dengan melakukan sosialisasi vaksin, warga memahami betul bagaimana ikhtiar yang dilakukan pemerintah sehingga terwujudlah kekompakan dan kerjasama antara warga dan 
pemerintah untuk bersama-sama melawan Covid-19 dengan mematuhi protokol kesehatan dan melakukan vaksin.

Ranting Kenjeran juga memiliki panti asuhan. Akan tetapi pengelolaan dan pembinaan anak yatim masih jauh dari kata baik.

\section{METODE PENELITIAN}

Kegiatan pemberdayaan masyarakat ini merupakan program Kuliah Kerja Nyata (KKN) yang mengambil tema Pengembangan Cabang dan Ranting (PCR). Perencanaan dan observasi kegiatan ini dilakukan dalam waktu satu bulan, dimulai Juli-Agustus. Sedangkan Pelaksaaan dan Evaluasi kegiatan dilakukan dalam waktu satu bulan juga, dimulai dari bulan Agustus sampai September 2021. Kegiatan ini dilakukan dengan menggunakan pendekatan model community development yaitu "upaya mempersiapkan masyarakat seiring dengan langkah memperkuat kelembagaan masyarakat agar mereka mampu mewujudkan kemajuan, kemandirian, dan kesejahteraan dalam suasana keadilan sosial yang berkelanjutan. (Pinariya et al., 2021).

Pemberdayaan masyarakat dapat dimaknai sebagai aktivitas orang-orang atau masyarakat untuk melakukan pengawasan terhadap kehidupan mereka sendiri dan berusaha untuk membentuk masa depan sesuai dengan kemampuan dan keinginan mereka sendiri (Isbandi Rukminto Adi, 2001)

Pemberdayaan masyarakat memiliki enam tujuan yang dianggap sesuai dengan pencapaian dalam program ini diantaranya adalah untuk perbaikan kelembagaan, usaha, pendapatan, lingkungan, kehidupan dan masyarakat (Mardikanto, 2014).

Untuk mencapai tujuan tersebut, diperlukan adanya partisipasi masyarakat dari setiap pelaksanaan pemberdayaan yang dilakukan untuk dapat merumuskan segala permasalahan yang ada pada masyarakat, sehingga pada akhirnya aksi pemberdayaan yang dilakukan tersebut dapat sesuai dengan kebutuhan dan harapan masyarakat. Pemberdayaan menekankan pada process goal, yaitu tujuan yang berorientasi pada proses yang mengupayakan integrasi masyarakat dan dikembangkan kapasitasnya guna memecahkan masalah secara kooperatif atas dasar kemauan dan kemampuan menolong diri sendiri (self help) sesuai prinsip demokratis (I. R. Adi, 2003).

Berdasarkan permasalahan yang dihadapi Cabang dan Ranting Muhammadiyah di Kecamatan Kenjeran, yang telah diidentifikasi, maka solusi yang ditawarkan dalam program KKN-PCR ini adalah Pendampingan dan Sosialisasi Cabang dan Ranting Muhammadiyah melalui Pendataan warga dan pendampingan mengurus KTA Muhammadiyah, perbaikan 
visualisasi informasi dan fasilitas masjid, Sosialisasi vaksin, Santunan anak yatim dan bentuk-bentuk aktivitas lainnya yang mendukung.

Mekanisme pembinaan dan pengembangan Cabang dan Ranting Muhammadiyah, serta mekanisme pembinaan dan pemberdayaan Cabang dan Ranting Muhammadiyah Kecamatan Kenjeran Kota Surabaya dapat dilihat pada Gambar 1 sebagai berikut:

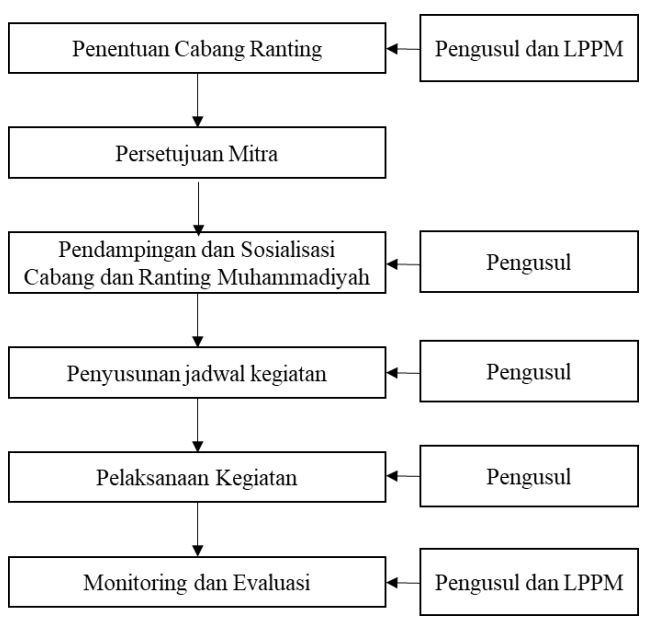

Gambar 1 Metode Pengabdian

Langkah-langkah yang akan dilakukan dalam pelaksanaan program KKN-PCR ini adalah sebagai berikut:

a. Sosialisasi program KKN-PCR untuk menyatukan persepsi tim pengusul dan mitra dalam

pelaksanaan program agar tidak terjadi miss komunikasi dan terkoordinir dengan baik.

b. Penyiapan sarana dan prasarana dibebankan pada mitra untuk menyesuaikan program kerja.

c. Penyiapan sarana dan prasarana yang dirancang dan dilaksanakan oleh tim pengusul. d. Pembinaan dan pemberdayaan Cabang dan Ranting Muhammadiyah antara lain melalui:

- Pendataan Anggota

- Pendampingan pengurusan KTA

- Pemakmuran Masjid

- Sosialisasi Vaksinasi

- Santunan Anak yatim

e. Monitoring dan evaluasi program untuk menjamin keberlanjutan dan pengembangan dari program KKN-PCR ini agar tidak terhenti setelah kegiatan KKN-PCR berakhir.

Pelaksanaan kegiatan KKN-PCR ini akan terlaksana dengan baik melalui kerjasama dan partisipasi aktif dari mitra. Selain partisipasi sebagai kelompok sasaran atau peserta dalam Pendampingan dan Sosialisasi yang akan dilaksanakan pada program KKN-PCR ini. Untuk perencanaan jangka panjang dan tindak lanjut program Pendampingan dan Sosialisasi ini, akan diadakan pendampingan atau dijadikan sebagai binaan kampus dalam hal ini ditangani oleh lembaga penelitian dan pengabdian masyarakat UMSurabaya bekerjasama dengan Lembaga Pembinaan Cabang dan Ranting Muhammadiyah Kota Surabaya. 


\section{HASIL DAN PEMBAHASAN}

Fenomena pandemi ini menjadikan Cabang Bulak Ranting Kenjeran memiliki kendala salah satunya data anggota Muhammadiyah terbilang belum lengkap dan diharapkan dengan adanya pendataan ulang anggota Muhammadiyah, akan memudahkan Analisa terkait program kerja yang bisa dilakukan di ranting kenjeran.

Sumber Daya Manusia (SDM) masih minim wawasan keilmuan namun lambat laun telah memahami kepentingan memperoleh pendidikan dan pemahaman mengenai protokol kesehatan dimasa pandemi ini. Cabang Bulak Ranting Kenjeran masih belum memiliki dan memadai informasi melalui media teknologi, sehingga pengenalan mengenai Ranting Kenjeran ini hanya melalui Pimpinan Cabang Muhammadiyah serta harapannya Ranting Kenjeran memiliki Website, Instagram, facebook, channel youtube dan sebagainya yang nantinya selalu berkembang dan dikenal melalui media sosial. Banyak aktivitas yang terkendala dan terbengkalai akibat pandemi. Beberapa hal yang bisa dilakukan kelompok pengabdian untuk menunjang pengembangan Ranting Kenjeran sebagai berikut:

\section{Pendataan dan pembuatan KTA}

Muhammadiyah merupakan organisasi Islam terbesar kedua di Indonesia. Baik dilihat dari sudut pandang anggota/simpatisan dan aktivitasnya. Anggota muhammadiyah tersebar ke seluruh pelosok negeri, bahkan banyak juga yang berada diluar negeri. Tentu demikian, perlu untuk mendata berapa banyak jumlah anggota muhammadiyah. Untuk menjadi anggota muhammadiyah pun mudah, bisa melalui offline dengan datang ke pimpinan daerah atau bisa melalui online. Biayanya pun tidak mahal, hanya 25.000-50.000, berlaku untuk seumur hidup. Akan tetapi dari proses survei yang kita lakukan di Ranting Kenjeran, masih banyak yang tidak mempunyai KTA (Kartu Tanda Anggota) Muhammadiyah. Masyarakat beralasan sulit untuk melakukan pembuatan KTA, ada juga yang sudah pernah membuat melalui pihak ketiga, tetapi sampai sekarang belum jadi. Banyak juga yang beralasan tidak tahu manfaat apa yang didapatkan setelah mempunyai KTA. Dari permasalahan ini, kami mengadakan kagiatan untuk melakukan sosialisai pembuatan, pendataan dan membantu warga untuk membuat KTA ke PDM Surabaya. 


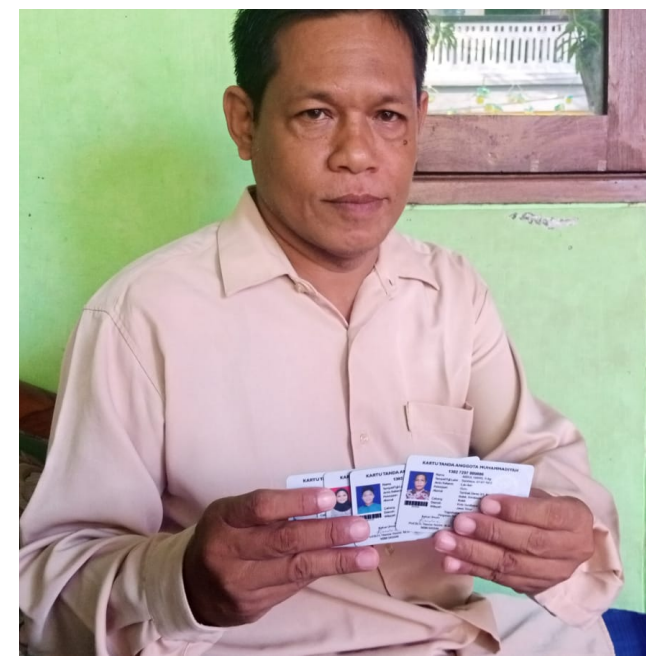

Gambar 2 hasil pendampingan pembuatan KTA

\section{Pemakmuran masjid}

Aktivitas Masjid Al-Mustoffa selama pandemi banyak terkendala. Kegiatan masjid yang sebelumnya rutin ada kajian setiap bulan, tidak bisa berjalan seperti sedia kala. Kondisi tersebut menjadikan masjid tidak terlalu terurus layaknya masjid. Sehingga kami dengan seizing takmir masjid melakukan penataan dan melengkapi informasi yang ada di Masjid Al-Mustoffa agar nanti setelah aktivitas berjalan sedia kala, masjid dapat langsung akselerasi untuk melakukan kegiatan-kegiatan dakwah dan pembinaan.

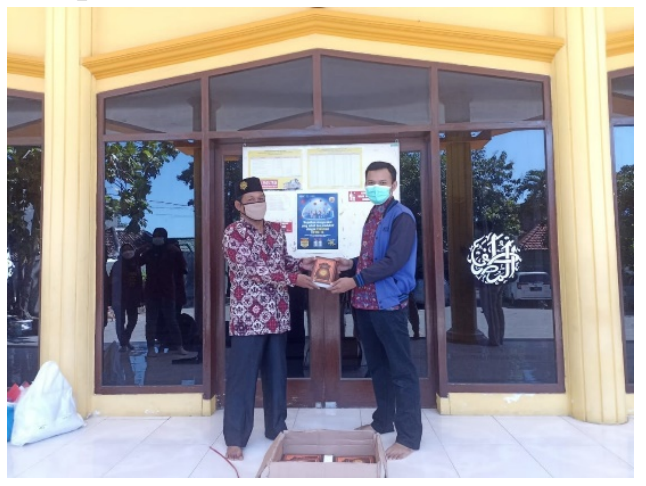

Gambar 3 Penyerahan Simbolis Alquran oleh Ketua Tim

\section{Sosialisasi vaksin}

Pimpinan Pusat

Muhammadiyah sangat fokus melakukan sosialisasi mengenai vaksin, bahkan langsung memberikan contoh kepada masyarakat dengan melakukan vaksinasi baik pimpinan pusat maupun daerah. Meskipun demikian banyak warga muhammadiyah yang masih enggan melakukan vaksin dikarenakan takut efek samping yang mematikan. Padahal vaksinasi dan protokol kesehatan merupakan kunci ikhtiar untuk terlepas dari pandemi Covid19. Dari hasil survey kita terkait vaksinansi di Ranting Kenjeran, ternyata, masih ada yang tidak mau divaksin dikarenakan tidak percaya adanya covid19. Sehingga kita secara bertahap melakukan sosialisasi secara door to door dengan membawa brosur vaksin yang sebelumnya sudah dibuat. Harapannya dengan melakukan pendekatan secara kultural, masyarakat bisa memahami tentang pentingnya vaksinasi dan tidak mudah terkena berita hoax.

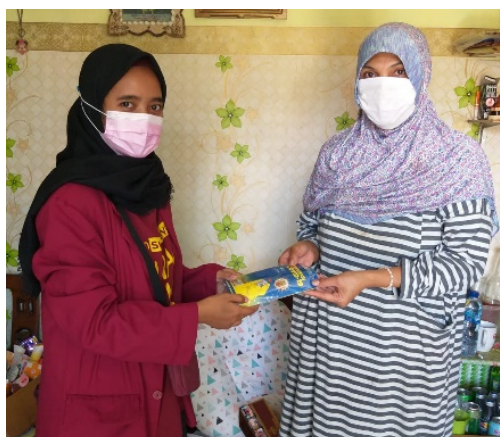

Gambar 4 Sosialisasi Vaksinasi ke warga 
4. Santunan panti asuhan

Penyebaran virus Covid19 varian delta yang sangat cepat, membuat pemerintah menarik rem darurat dengan menerapkan PPKM. PPKM Darurat yang dilakukan lebih dari satu bulan tentu menjadi pukulan telak bagi pekerja harian. Hal ini tentu berdampak pada ekonomi masyarakat. Apalagi bagi mereka yang secara ekonomi tanpa adanya pandemi pun sudah kesulitan keuangan. Salah satunya adalah para anak yatim piatu. Ranting Kenjeran memiliki Panti Asuhan dengan beberapa anak asuh. Untuk meringankan beban ekonomi mereka, kelompok KKN memberikan bantuan bingkisan paket sembako.

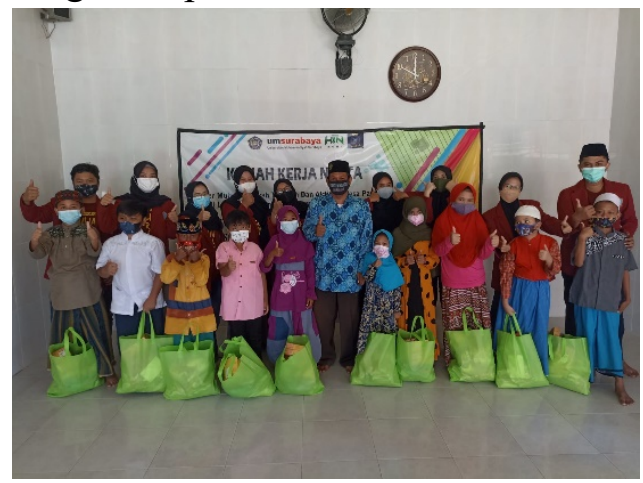

Gambar 5 Santunan yatim piatu

\section{SIMPULAN}

Pendampingan dan Sosialisasi Cabang dan Ranting Muhammadiyah di masa pandemi covid19 dapat dilaksanakan beberapa kegiatan yaitu Pendataan warga muhammadiyah, pemakmuran masjid, Sosialisasi vaksinasi, santunan anak yatim, dan kegiatan lain dengan tetap menaati protokol kesehatan. Kondisi ekonomi mengalami keterpurukan selama pandemi. Hal menjadi tantangan bagi Cabang dan Ranting Muhammadiyah untuk memberikan solusi atas permasalahan ini, oleh karena itu program pemberdayaan tidak boleh juga dilupakan.

Kegiatan pengabdian kepada masyarakat perlu dilakukan secara berkesinambungan agar pembinaan sebelumnya dapat berlanjut secara simultan, sehingga akan terlihat hasilnya secara baik. UMSurabaya sebagai institusi pendidikan yang berada di bawah naungan Muhammadiyah perlu memberikan perhatian besar pada pembinaan dan pemberdayaan Cabang dan Ranting Muhammadiyah agar Muhammadiyah lebih kokoh dan lebih terasa keberadaannya di Masyarakat. Kegiatan KKN-PCR ini harus tetap diprogramkan setiap tahun agar kegiatan pengabdian tidak hanya menyasar masyarakat umum, tetapi juga berkontribusi ke persyarikatan.

\section{DAFTAR PUSTAKA}

Anwar, H. 2008. Teori Vygotsky Tentang Pentingnya Strategi Belajar.

Adi, I. R. 2003. Pemikiran-Pemikiran dalam Pembangunan Kesejahteraan Sosial (Seri Pembe). Fakultas Ekonomi Universitas Indonesia.

Adi, Isbandi Rukminto. 2001. Pemberdayaan, Pengembangan Masyarakat dan Intervensi Komunitas. Lembaga Penerbit Fakultas Ekonomi Universitas Indonesia. 
Falahuddin. 2020. Respons Muhammadiyah Menghadapi Covid-19. Maarif, 15, 137-152. https://doi.org/10.47651/Mrf.V1 5 i1.81

Halim, I., Tinggi, S., Ekonomi, I., \& Palopo, M. 2018. RESONA KKN-PPM Pembinaan dan Pemberdayaan Cabang- Ranting Muhammadiyah Kecamatan Mangkutana Kabupaten Luwu Timur. 2(1), 57-63.

Harahap, P., \& Lubis, S. 2020. Pelatihan Pembuatan Peta Cabang Dan Ranting Muhammadiyah Menggunakan Aplikasi Sicara Untuk Mercepatan Pemetaan Cabang Dan Ranting Muhammadiyah Se-Kota Medan. 2(1), 14-21.

Hartono, H., \& Yusuf, Y. 2021. Tinjauan Molekuler dan Epidemiologi Mutasi pada Virus SARS-CoV-2. Bionature, 22(1), 43-49.

https://doi.org/10.35580/bionatu re.v22i1.22379

Ichsan, M. 2020. Islamic Philantrophy and Muhammadiyah's Contribution to the Covid-19 Control In Indonesia. Afkaruna, 16(1), 114-131.

https://doi.org/10.18196/aiijis.2 020.0116.114-130

Ma`arif, A. S. 2000. Muhammadiyah: antara Praksisme dan Intelektualisme Islam. Muhammadiyah University Press.

Mardikanto, T. 2014. Corporate Social Responsibility (Tanggung Jawab Sosial Korporasi). Alfabeta.

Pinariya, J. M., Forceila, D., Ivana, L., \& Yunia, A. 2021. Sosialisasi dan Edukasi Digital Marketing pada Komunitas BGBJ. Aksiologiya, 5(2), 191-202. 